\title{
MEDICO-LEGAL ISSUES IN VICTORIAN MEDICAL CARE
}

by

\section{ROY M. MACLEOD}

The medico-legal issues raised by 'conscientious objection' constitute a particularly revealing, though hitherto neglected instance of the emerging relationship between community responsibility and personal health during the late Victorian period. The following paragraphs seek to indicate the relevance of a medico-legal approach to Victorian social history, and to suggest certain areas of research that may well repay closer study.

The origins of the term 'conscientious objector' are obscure. In Britain, apart from nominal application to the non-conformist movement in public education, and its later application to wartime services, it has had major significance in regard to the anti-vaccinationist movement during the last quarter of the nineteenth century. Indeed the term seems to have been conferred first on religious antivaccinationists in particular, and subsequently by the Vaccination Act of 1898 on all parents who expressed scruple of any kind against the vaccination of their children. We must, therefore, consider the term in its religious sense, and later suggest the importance of its broader usage.

The religious conscientious objector in the nineteenth century attracted public attention by his refusal to participate in, or accept the principles of, either allopathic medical treatment or certain generally accepted medical preventives. By definition, this refusal was predicted upon adherence to particular religious beliefs which professed to be incompatible with the customary medical practices of the day. Such beliefs were ascribed to members of the Christian Science faith in its early years, and to members of the Peculiar People and other 'faith healing' sects. The Peculiar People, perhaps the paradigm example, based their own medical practices upon scriptural texts, notably James v: 14-15:

Is any sick among you? Let him call for the elders of the church and let them pray over him, anointing him with oil in the name of the Lord: and the prayer of faith shall save the sick and the Lord shall raise him up; ...

For the most part, their activities do not seem to have caused legal action unless the object of the treatment suffered death as an apparent result of that treatment. In this case, the religious issue phased into and became lost amid more complicated arguments of quackery and malpractice.

It is helpful to illuminate the subject by briefly outlining the historical development of the public reaction to conscientious objection. Accordingly, one may distinguish between those actions taken in respect of adult members of society who opt for heteropathic treatment on whatever grounds, and those taken in respect of children whose parents are suggestibly liable for malfeasant neglect in the event of death. In 


\section{Medico-Legal Issues in Victorian Medical Care}

the nineteenth century, the former was adjudicated usually on the grounds of medical practice; the latter, on grounds of parental irresponsibility. Within these two frames of reference, two different reformist ideologies evolved, one arising from medical or paramedical professionalism, in which protest was concentrated in, and on behalf of, the medical profession; the other engendered by public sentiment against ignorant religious objection, sentiment itself largely of humanitarian or quasi-religious origin.

In the case of death caused by the employment of a medical attendant, or of any person assuming responsibility for the care of the sick, by an individual who has freely chosen that attendant or practique, the charge of manslaughter was sometimes pressed. In the early nineteenth century the 'regular' medical profession urged such charges, usually with little success because it could always be stated in defence that the medical attendant, by religious prayer or otherwise, fully intended to cure the patient, and one could not be convicted of manslaughter unless one was engaged in an 'unlawful act'. In colonial Massachusetts, where such a case was first tried (Commonwealth v. Thomson, 6. Mass. 134), Lord Hale was cited in the decision that no man could be forbidden from prescribing honestly for a sick man with the latter's consent. This decision, specifically applied to the 'Thomsonian' school of heteropathy, seemingly could have applied to religious healers as well, although there is no evidence that it in fact did. Further cases ${ }^{1}$ supported this decision, until a comprehensive review was undertaken by the supreme court of Massachusetts (Commonwealth v. Pierce, 138 Mass. 165) in 1884. By its decision, the issue of medical misadventure must be considered on the basis of 'common experience', that is, whether danger could be commonly supposed to arise from such treatment, however well-intentioned. The advance of medical science apparently made "common experience' reliable, and judicial opinion confident.

Whether or not faith-healing was actually a practice of medicine, and liable to malpractice decision, depended largely on local definitions of medical practice. In New York, as late as 1887, medical practice was not defined, allegedly because one senator declared that a definition would exclude an eccentric healer who had saved his own life. ${ }^{2}$ In Nebraska, the state medical act defined a practitioner as one 'who shall operate on, or profess to heal, or prescribe for, or otherwise treat any physical or mental ailment of another'. And in the same state, in 1894, the courts ruled against a Christian Science practitioner, deciding that:

The exercise of the art of healing for compensation whether exacted as a fee or expected as a gratuity cannot be classed as an act of worship. Neither is it the performance of a religious duty...

The practitioner involved was prosecuted for unlawful practice of medicine. ${ }^{3}$ In this regard, the different character of English medical law, guaranteeing the freedom of medical practice with restrictions only against false advertisement of 'qualification' on the part of non-regularly qualified practitioners, has been formally less severe.

\footnotetext{
${ }^{1}$ New York: Marsh v. Davison 1842 (9 Paige 580). Missouri: Rice v. The State 1844 (8 Mo. 561).

2 For this and supporting references see William Purrington, Manslaughter, Christian Science, and the Law, Medical Record, 1898, 54, 757-761, reprinted in Christian Science: A Plea for Children and other Helpless Sick, New York, E. B. Treat \& Co., 1900.

- The State v. Buswell (40 Neb. 158), 1894. cf. Ibid. p. 760.
} 


\section{Roy M. MacLeod}

The less explored facet of conscientious objection, however, is that concerning the problem of parental responsibility. Here again, the actions undertaken against conscientious objectors sometimes provide our best information about their beliefs. The first case to achieve Victorian notoriety was Reg. v. Wagstaffe in January 1860 (10 Cox. CCJ 30). In this instance, two parents, members of the Peculiar People sect, were indicted for the manslaughter of their child. The charge was based on their inattention to medical treatment for the child, who was suffering from diarrhoea and pneumonia; their resort to prayer was ineffective. The task of the court was one of deciding whether this 'treatment', or lack of treatment, constituted 'neglect' of the child. Justice Willes held that where parents so acted from conscientious religious conviction, and not from any intention to avoid their duty, there was not culpable homicide. If the child had died from want of food, the case for neglect would have been manifest, but the decision to pursue a different course of 'medical care' at a time when the efficacy of many allopathic cures was not beyond doubt, could not constitute manslaughter.

Seven months after this decision, in July 1868, the Poor Law Amendment Act (31 \& 32 Vict c. 122) was passed. Clause 27 of the Act, introduced specifically to give statutory definition to the word 'neglect', prescribed an offence to arise:

when any parent shall wilfully neglect to provide adequate food, clothing, medical aid or lodging for his child, being in his custody, under the age of 14 years, whereby the health of such child shall have been or shall be likely to be seriously injured.

This, of course, altered the legal position completely, and in 1875, Lord Coleridge, LJ, confirmed a conviction against a parent who had abstained from medical treatment on religious grounds (Reg. v. Downes, 45 LJMC 8: 1 Q.B.D. 25). In 1889 and 1894, however, passage of the Prevention of Cruelty to Children Acts had the unintentional effect of repealing Clause 27 of 1868. Instead of the previous requirement for parents to 'provide medicines, food, etc.' for their children, Clause 1 of the 1889 Act merely forbade 'neglect' of the child. What definition had been achieved in 1868 seemed inadvertently to have been abandoned in 1889 and in the subsequent Act of 1894 .

The fact of this apparently retrogade action was brought to light four years later in Reg. v. Senior (68 LJQB 175). This case was significant for two major reasons: first, it set precedent for most subsequent judicial actions of this kind, and second, it effectively demonstrated, as the Massachusetts case had done for medical practice in 1884 , that medical science had achieved sufficient reliability to permit just accusal of anyone denying the benefits of this knowledge to anyone else, regardless of reason. There was now, it seemed, a consensus of public opinion, quite apart from medical opinion, which testified to the existence of a minimum acceptable standard of individual medical care, which, were the logic fulfilled, would be recognized as the birthright of every British child. In this case, the father, George Senior, a carman by vocation, was also a member of the Peculiar People sect. His beliefs had not hitherto aroused the intervention of the law, although seven of his twelve children had, for unstated reasons, died. Testimony revealed that he was a 'kind father'; now, however, another of his children, eight months old, had died, and medical evidence was given to the effect that its life would have been prolonged, and probably saved, if medical 


\title{
Medico-Legal Issues in Victorian Medical Care
}

assistance had been secured. Senior was convicted by Justice Willes in November 1898, and the case was bound over to the Court of Crown Cases Reserved. Defence cited the decisions in Reg. v. Wagstaffe, and Lord Coleridge's opinion in Reg. v. Downes, and rested on the plea that Senior believed the use of medicines would harm his child. In view of Clause 1 of the 1889 and 1894 Acts there must be, it was insisted, evidence of intentional and wilful neglect in order to justify conviction.

Their Lordships, however, disagreed. Lord Russell of Killowen, LJ, doubted that the Acts of 1889 and 1894 intended a retrograde step, felt assured, in any case, that conviction under the 1868 Act was both possible and proper, and confirmed the decision of Justice Willes. Justice Grantham, concurring, sidestepped the religious issue and expressed the view that Senior left the child without medical aid and therefore acted wilfully, and with wilful neglect.

Senior was sentenced to four months imprisonment at hard labour. The decision rendered was as follows:

\begin{abstract}
A person over the age of 16 who, having the custody, charge or care of a child under that age, fails by reason of holding certain religious views to provide medical aid to such child, when ill, so as to cause unnecessary suffering or injury to its health, is guilty of wilful neglect within the meaning of Sec. 1 Sub Sec. 1 of the Prevention of Cruelty to Children Act, 1894 and should such child die, or its death be accelerated through such wilful neglect, he is guilty of manslaughter ... 'neglect' ... means that the absence of such reasonable care as an ordinary parent would ordinarily use for the protection and care of his child-the failure to take such steps for the protection of infant life and health as the general experience of mankind shows to be proper, provided that the means of rendering such treatment be within the reasonable competence of the person on whom the duty to render it rests.
\end{abstract}

The phrase, 'the general experience of mankind' is particularly significant when we turn to consider the issue of conscientious objection towards compulsory smallpox vaccination. In 1898, the Salisbury Government acted upon the long-deliberated recommendations of the Royal Commission on Vaccination (1889-1896), and, inter alia, allowed parents to obtain exemption for their children from the vaccination laws by convincing a stipendiary magistrate of their 'conscientious objection' to vaccination. ${ }^{5}$ Such an objection was widely held by the Peculiar People, and was based on the belief that vaccination would adversely affect the health of the child. Vaccination for smallpox, however, was one of the most significant contributions of medicine to society, and was traditionally counted among the values unquestioned by 'the general experience of mankind'. Why then, in view of the Senior incident and the Vaccination Act, was the 'general experience of mankind' considered sufficiently reliable to warrant faith in medical treatment of every kind, yet at the same time unreliable enough to excuse the parent from his obligations to accept the most generally acknowledged preventive against one of the most devastating infectious diseases? At the same time that the criminal law courts determined not to allow 'conscientious objection' for matters of personal health, where the lives of only a few children would be concerned, the Government was quite distinctly making allowance for conscientious objection, where the lives of a great proportion of the infant population were at stake.

4 Legal Notes, J. State Med., 1899, 7, 122-3; Lancet, 1898, ii, 41, 587, 1651, 1716-17.

s 61 \& 62 Vict. c. 49. Cf. Final Report of the Royal Commission on Vaccination, 1896, [c.8270] xlvii. 


\section{Roy M. MacLeod}

A paradox is clearly evident here, a consideration of which points to the existence of considerable uncertainty in the public mind about the status of medical methods. Moreover, this paradox suggests that tendencies towards Shavian distrust of the medical profession, which were to become overt in the Edwardian period, ${ }^{6}$ were being kindled well before $1900 .^{?}$

The vaccination issue forcibly illustrates the relevance of this distrust and uncertainty to the study of Victorian society. During the last quarter of the century, the antivaccinationist movement had succeeded in bringing into opportunistic alliance variant groups of hydrotherapists, nature-cure faddists, and religious faith-healers. Their arguments against vaccination ranged from post-Jennerian moral outrage at the thought of introducing the 'diseased blood of a foul brute' into the arms of pure children, to more legitimate fears about safety of the operation upon newborn infants, the possibility of post-vaccinal complications, and the danger of transmitting constitutional disease from child to child by the then time-honoured arm-to-arm technique. ${ }^{8}$ After one of the most vociferous protest movements in Victorian history, this objection aroused latent medical uncertainties as well, and forced a reversal in the pattern of State intervention. ${ }^{9}$

What explanation can be given for the apparently paradoxical attitude of the State towards conscientious objection to methods of treatment, and conscientious objection to methods of prevention? First, it may be suggested that while public confidence in the medical profession was broadly acknowledged in most general matters on which there was little difference of professional opinion, the same support was not forthcoming in matters of a speculative character affecting specific public interests, about which doctors so distinctly differed. Second, while society could not excuse the overt omission of parental responsibility in the face of prima facie ill-health, it could assert a public right to question a matter of Government or professionally enforced practique, which was debatable both on grounds of the likelihood of ill-health arising from its neglect and on the grounds of dangers arising from the operation itself. ${ }^{10}$

The vaccination issue, gathering momentum from judicial interpretation, had clear long-term legislative results. When, in 1908, the Departmental Committee on Inebriates reported that 'The fate of the Vaccination Acts makes it evident that no

- G. B. Shaw, The Doctor's Dilemma: A Tragedy, London, Constable \& Co., 1913.

7 G. M. Gould, Is medicine a science?, Forum, 1889, 8, 417; H. J. Wiley, What is wanting?, Indiana J. Med., 1874, 4, 528, cited in W. L. Fox, What is Wanting, Bull Hist. Med., 1962, 36, 270; Medicine and society, Nineteenth Century, 1895, 37, 1027; The medical profession and its morality, The Modern Review, 1881, 2, 300.

- See E. Haughton, Fallacies of the inoculators, Westminster Review, 1889, 152, (I): 214-219; (II): 471-474. W. D. Hidden, Dangers of vaccination, North American Review, 1899, 159, 124-127. Sir J. Clarke Jervoise, Infection, London, Vacher \& Sons, 1882. J. H. Bridges, The moral and social aspects of health, Fortnightly Review, 1878, 28, 562-580.

- This aspect will be treated fully in my forthcoming study of the decline and fall of the State Vaccination Services.

${ }^{10}$ For comments upon the social conception of 'professional despotism', see T. H. S. Escott, Social Transformations of the Victorian Age, New York, 1897, p. 396. 


\section{Medico-Legal Issues in Victorian Medical Care}

mode of medical treatment can be successfully enforced by Act of Parliament, and that any attempt to enforce it would produce more friction, discontent, and agitation than it was worth.'11 it was clear that the enforcement of resisted law had itself created fresh law-making opinion. ${ }^{12}$ The fact that large numbers of children - between 1898 and $1901,54-77 \%$ of infants under one year of age - were released from the requirement of vaccination by the award of 'Conscientious Objection Certificates' indicates that the medico-legal issue at stake was one of broad social significance. ${ }^{13}$ When it is considered that to a large extent the 'conscientious objector' under the Vaccination Act of 1898 objected for reasons other than personal whim or religious doctrine, it is clear that useful correlations may be drawn with the social protests against diptheria-antitoxin, ${ }^{14}$ and against the compulsory notification of infectious diseases. ${ }^{15}$

Finally, further study of the individuals and groups which protested against certain widely accepted medical beliefs may reveal that these same individuals and groups played an important role in movements against state education and state intervention in general. Indeed the medico-legal approach, by examining these and other apparent anomalies, may permit further insight into the religious, moral and philosophical disquiet existing during this time of rapid development in medical science and public policy. At the very least, the factors which at first seem inconsistent with traditional historical interpretation may point the way to a closer study of 'science and anti-science' during the Victorian period, and may project new formulations about the changing attitudes of Government and society towards personal medical care.

11 Report of the Departmental Committee appointed to inquire into the operation of the Law relating to Inebriates, and to their Detention in Reformatories and Retreats, 1908. Cd. 4438. xii. para. iv.

12 A. V. Dicey, Law and Public Opinion in England during the Nineteenth Century, London, 1905

pp. 41-47. Dicey's classic work leaves the vast region of medical-legal research unexplored, but suggests the relevant background against which further studies into the nineteenth century 'revolution in government' may be set.

${ }^{13}$ C. Killick-Millard, The role of the 'anti': an apology and an appeal, Public Health, January 1903. For the broader implications of some antivaccinationists' ambitions, see Francis W. Newman, The Coming Revolution, Nottingham, 1903.

${ }^{14}$ Lancet 1898, ii, 1070.

${ }_{16}$ R. Hamilton, Compulsory Notification of Infectious Diseases, London, 1883, p. 46; W. H. Michael, Is it desirable that there should be a system of compulsory Notification of Diseases ? London, 1881. 